Functional

Ecology 2005

19, 785-793

\title{
Specific functional signature in soil macro-invertebrate biostructures
}

\author{
M. HEDDE, $* \dagger$ P. LAVELLE, + R. JOFFRE,§ J. J. JIMÉNEZף and T. DECAËNS* \\ *Laboratoire d'Ecologie, UFR Sciences, Université de Rouen, F-76821 Mont Saint Aignan Cedex, France, \\ $\$$ Laboratoire d'Ecologie des Sols Tropicaux, Centre IRD, 32 avenue Henri Varagnat, F-93143 Bondy, France, \\ $\S$ Centre National de Recherche Scientifique, Centre d'Ecologie Fonctionnelle et Evolutive, 1919 route de Mende, \\ F-34293 Montpellier Cedex 5, France, and $₫$ Carbon Management and Sequestration Center, The School of Natural \\ Resources, The Ohio State University, 2021 Coffey Road, Columbus, OH-43210, USA
}

\begin{abstract}
Summary
1. The aim of this study was to search for specific signatures of biogenic structures (i.e. earthworm casts, termite sheathings and mound material, and ant deposits) made by 15 species of soil engineers in a Colombian savanna. We thus investigated the organic matter (OM) biochemical composition of biostructures using near infrared spectroscopy (NIRS) and its relationship with selected biological (respirometry) and chemical attributes.
\end{abstract}

2. We found significant differences in $\mathrm{OM}$ quality and potential respiration rate among biostructures. These results were attributed to production patterns of biostructures and invertebrate feeding behaviour. A multiple co-inertia analysis was performed with NIRS, respirometry and chemical results. It separated (i) carton termite mounds, (ii) earthworm casts and organo-mineral termite mounds and (iii) termite sheathings and ant deposits.

3. These results suggest that NIRS spectra might be used as 'fingerprints' to identify organisms responsible for soil aggregate production. Moreover, the ordination given by the co-inertia analysis is proposed as a basis for a functional classification of soil engineers, assuming that different biostructure properties imply different effects on soil functioning.

Key-words: Near infrared reflectance spectroscopy, physical ecosystem engineers, soil aggregates, soil organic matter

Functional Ecology (2005) 19, 785-793

doi: $10.1111 /$ j.1365-2435.2005.01026.x

\section{Introduction}

The effect of invertebrate diversity on soil function has been addressed in a number of experiments and models. Most studies give foodweb complexity a central role in the top-down control of nutrient cycling (de Ruiter, Neutel \& Moore 1998; Moore et al. 2003), with predation regulating primary decomposer abundance and activity and the rate of release of mineral $\mathrm{N}$ and $\mathrm{P}$. However, these models tend to ignore the effect of physical processes, such as the combination of elementary particles in aggregates of different compositions and sizes, and the abundance and size distribution of pores that determine fluxes of oxygen and water and the access of organisms to feeding resources.

Earthworms, termites and ants are 'physical ecosystem engineers' (sensu Jones, Lawton \& Shachak 1994) $\uparrow$ Author to whom correspondence should be addressed. E-mail: mickael.hedde@etu.univ-rouen.fr that significantly influence soil organic matter (OM) dynamics, hydraulic properties and ultimately pedogenetic processes by producing solid organo-mineral structures (Lavelle 1996; Lavelle \& Spain 2001). These structures are highly diverse, and widely distributed above (e.g. mounds, nests, sheathings or casts) and below (e.g. galleries or chambers, earthworm and termite casts) ground. They are considered as microsites where macro-scale ecosystem processes are regulated (Anderson 1993; Lavelle et al. 2004a) and affect the diversity of other organisms, from microorganisms to macrofauna (Loranger et al. 1998; Decaëns, Mariani \& Lavelle 1999; Diouf 2003; Mora et al. 2003). Declines in the abundance and diversity of invertebrate engineer communities induced by inadequate soil management may actually impair soil hydraulic function and severely decrease plant production (Chauvel et al. 1999). Hence, the diversity of biostructures produced by ecosystem engineers has been hypothesized to represent the major functional attribute whereby macro-invertebrate diversity influences soil functioning (Lavelle 1996). 
Although a few studies have addressed the diversity of these structures (Schrader \& Zhang 1997; Decaëns, Galvis \& Amezquita 2001; Davidson et al. 2002), their recognition once incorporated in the soil matrix has so far been impossible, and this has impeded identification of relationships between changes in soil engineer diversity, the diversity of structures produced and relevant indicators of soil function. Identifying specific signatures of soil invertebrate engineers in a range of biostructures is therefore a highly challenging topic for soil ecology. This would allow determination of the exact origin of any aggregate in the soil, and open new perspectives for explanative and predictive modelling of the mechanisms involved in the formation and dynamics of soil structure.

In the present study, we tested the ability of near infrared spectroscopy (NIRS) and a few other classical analytical techniques to discriminate biogenic structures produced by different species of soil macroinvertebrates. NIRS allows a rapid, sensitive, non-destructive and accurate qualitative analysis of the molecular composition of an organic sample. It is an increasingly accepted tool for academic research in many areas ranging from chemistry to agriculture and from life science to environmental assessments (Foley et al. 1998; Joffre et al. 2001; Siesler 2002; Shepherd \& Walsh 2002; Demattê et al. 2004). The objectives of our work were (i) to identify specific signatures for the biostructures produced by 15 ecosystem engineers in a Colombian savanna based on NIRS spectra and (ii) to compare this ordination with similar classifications based on standard chemical and microbiological properties to establish a functional classification of these biostructures.

\section{Materials and methods}

\section{STUDY SITE}

The study was carried out at the Carimagua Research Centre (CIAT-CORPOICA), Meta, Colombia $\left(4^{\circ} 37^{\prime} \mathrm{N}\right.$, $\left.71^{\circ} 19^{\prime} \mathrm{W}\right)$, which is located in the 'Llanos Orientales' (eastern plains) of the Orinoco basin. Climate is tropical subhumid with an average annual rainfall of $2300 \mathrm{~mm}$, a dry season extending from November to March, and an annual average temperature of $26^{\circ} \mathrm{C}$. Sampling was done in a well-drained Oxisol covered by a grassy natural savanna dominated by Trachypogon vestitus Andres and Paspalum pectinatum Nees. Vegetation was protected from cattle grazing and burnt once a year during the dry season.

\section{BIOSTRUCTURE SAMPLING}

Engineer invertebrates and their fresh above-ground biostructures were collected in November 2001. Specimens were identified at the generic or specific level (see the list of taxa in Table 1). Depending on their availability, 3 to 13 samples of 5-20 g dry material were taken for each biostructure, giving a total of 134 samples (see details in Table 1). All samples were air-dried for 1 week, crushed and sieved at $2 \mathrm{~mm}$. Four control soil samples were also collected in the savanna plot to a depth of $10 \mathrm{~cm}$ with a $5-\mathrm{cm}$ diameter cylinder. Their location was chosen at random, at least $10 \mathrm{~m}$ apart from any biostructure present at the soil surface.

\section{SPECTROSCOPIC MEASUREMENTS}

The NIRS characterizes the molecular composition of $\mathrm{OM}$ in soil samples by analysing reflected spectra of

Table 1. List and main characteristics of the soil engineers and their above-ground biostructures. Alimentary diet: $\mathrm{A}=$ anecic; $\mathrm{G}$ = geophagous; $\mathrm{L}=$ leaf-cutting; $\mathrm{N}=$ nectivorous; $\mathrm{O}=$ omnivorous; $\mathrm{P}=$ polyhumic endogenous (Decaëns et al. 2001)

\begin{tabular}{|c|c|c|c|c|c|}
\hline \multirow[b]{2}{*}{ Species } & \multirow[b]{2}{*}{ Diet } & \multicolumn{4}{|l|}{ Biostructures } \\
\hline & & Type & Aspect & Species code & Sample number \\
\hline \multicolumn{6}{|c|}{ Ants (Hymenoptera, Formicidae) } \\
\hline Atta laevigata & $\mathrm{L}$ & Mineral mound & Light rubble heap & A1 & 13 \\
\hline Camponotus sp. & $\mathrm{O}$ & Mineral mound & Light rubble heap & $\mathrm{A} 2$ & 13 \\
\hline Crematogaster sp. & $\mathrm{N}$ & Mineral mound & Light rubble heap & A3 & 10 \\
\hline Pheidole sp. & $\mathrm{O}$ & Mineral mound & Light rubble heap & A4 & 10 \\
\hline Acromyrmex landolti & $\mathrm{L}$ & Mineral mound & Light rubble heap & A5 & 3 \\
\hline Acromyrmex sp. 2 & $\mathrm{~L}$ & Mineral mound & Light rubble heap & A6 & 10 \\
\hline Acromyrmex sp. 3 & $\mathrm{~L}$ & Mineral mound & Light rubble heap & A7 & 10 \\
\hline Trachymyrmex sp. & $\mathrm{L}$ & Mineral mound & Light rubble heap & A 8 & 4 \\
\hline \multicolumn{6}{|c|}{ Termites (Isoptera, Termitidae) } \\
\hline Microcerotermes sp. & $\mathrm{G}$ & Carton mound & Carton material & $\mathrm{T} 1$ & 13 \\
\hline Velocitermes sp. & G & Organo-mineral mound & Cemented material & $\mathrm{T} 2$ & 13 \\
\hline Spinitermes sp. & G & Organo-mineral mound & Cemented material & $\mathrm{T} 3$ & 10 \\
\hline Ruptitermes sp. & G & Sheathings & Cemented rubbles & $\mathrm{T} 4$ & 10 \\
\hline Termite sp. & G & Carton mound & Carton material & T5 & 5 \\
\hline \multicolumn{6}{|c|}{ Earthworms (Oligochaeta, Glossoscolecidae) } \\
\hline Martiodrilus sp. & A & Casts & Compact material & E1 & 5 \\
\hline Andiodrilus sp. & $\mathrm{P}$ & Casts & Compact material & E2 & 5 \\
\hline
\end{tabular}

(C) 2005 British Ecological Society, Functional Ecology, 19, 785-793 


\section{Functional} signature in soil macro-invertebrate biostructures
(C) 2005 British

Ecological Society, Functional Ecology, 19, 785-793 material exposed to radiative energy in the infra-red region (Reeves, McCarty \& Meisenger 1999; Gillon, Houssard \& Joffre 1999; Joffre et al. 2001). Five grams of each sample were packed into a quartz-glass cell and scanned with a NIRSystems analyzer 6500 spectrophotometer (NIRSystems, Silverspring, USA). Two reflectance measurements of monochromatic light were made from 400 to $2500 \mathrm{~nm}$ to produce an average spectrum with 1050 data points at $2 \mathrm{~nm}$ intervals over this range with a $0.5 \mathrm{~nm}$ wavelength accuracy. The band-pass used is $10 \mathrm{~nm}$ (thus leading to 103 reflectance values). Reflectance $(R)$ is converted to absorbance $(A)$ using the following equation:

$A=\log (1 / R)$.

Spectral data were processed with the ISI Software System (Shenk \& Westerhaus 1991).

\section{CHEMICAL AND BIOLOGICAL ANALYSES}

Analyses of total nitrogen and other minerals were carried out for 11 of the 15 identified biostructures (those for which a sufficient amount of material was available; details in Tables 1 and 2) and on control soil according to methods recommended by the Tropical Soil Biology and Fertility program (Anderson \& Ingram 1993).

Respiratory activity $\left(\mathrm{CO}_{2}\right.$ release) was measured in standard laboratory conditions to assess the decomposability of OM. Samples of the 15 biostructures were placed in 320-ml glass bottles, and sterile sand was added to achieve a total weight of $50 \mathrm{~g}$; moisture was maintained at field capacity with sterile distilled water. Bottles were hermetically closed and placed in an incubator at $28^{\circ} \mathrm{C} . \mathrm{CO}_{2}$ measurements were realized after 1, 5, 8, 12, 14, 16, 19 and 21 days of incubation, with a BERYL-100 NDIR Analyser, Cosma spectrophotometer (Cosma Environment, Igny, France). Organic carbon was also measured to express results in $\mathrm{C}-\mathrm{CO}_{2}$ $\mathrm{g} \mathrm{carbon}^{-1}$.

\section{DATA ANALYSIS}

A principal component analysis (PCA) of spectral data was computed to make an ordination of the biostructures (103 columns, i.e. number of variables = absorbance, and 134 rows, i.e. number of objects = samples). To facilitate the factorial interpretation, samples were grouped either according to engineer taxa or to five broad biostructure types, i.e. earthworm casts, organomineral or carton termite mounds (sensu Lavelle \& Spain 2001), termite sheathings and ant nests. Group significance was tested by a permutation test (1000 permutations). Control soil samples were projected as additional rows in the analysis.

A multiple co-inertia analysis (ACOM) (Chessel \& Hanafi 1996) was performed among NIRS, respirometry and chemical properties to highlight similar patterns among data sets. The ACOM analysis is a method of simultaneous ordination of $K$-tables (or matrices) that share the same variables or the same objects. A compromise factorial plan that maximizes the co-inertia between these $K$ initial matrices is generated, and variables and objects of the initial $K$-matrices are projected on this plan in a simultaneous graphical representation. In the present case, the ACOM was applied to biostructures produced by 11 species for which complete data sets were available (Table 2). Matrices were constructed with the mean values of each parameter for each species. Hence, the three matrices contained 11 lines (i.e. the number of engineer species), and, respectively, 103, 11 and 8 columns for matrices made with NIRS, chemical and respirometry data, respectively. PCA, ACOM and related figures were created using the ADE-4 software (Thioulouse et al. 1997).

Comparisons of means were performed using Fisher PLSD test $(P<0.05)$. Prior to this, data normality was tested using a Kolmogorov-Smirnov test ( Lilliefors 1967), using VerNorm 3.0 software.

\section{Results}

\section{PRINCIPAL COMPONENT ANALYSIS OF NIRS SPECTRA}

The first and second axes of the NIRS matrix PCA absorbed $64 \cdot 1 \%$ and $12 \cdot 8 \%$ of the total inertia, respectively (Fig. 1). Owing to the sharp decrease of eigenvalues, no other axes were retained for interpretation (Fig. 1a). Variables representing wavelengths were diversely correlated with the first two axes, although it was not possible to specify which chemical compound was represented by each wavelength intensity (Fig. 1b). Species ordination was significant at $P<0.001$, and the first axis separated termite mounds and earthworm casts from ant structures and termite sheathings (Fig. 1d). The second axis mostly separated Microcerotermes sp. and Atta laevigata structures from Spinitermes sp. nests. Projections of the bulk soil samples on the first factorial plan were located in the neighbouring of organo-mineral earthworm casts and termite mounds on axis 1 , and displayed very high positive values on axis 2 .

\section{CHEMICAL PROPERTIES}

When compared with the bulk soil, earthworm casts and termite mounds presented higher $\mathrm{OM}$ and nutrient levels, and higher $\mathrm{pH}$ and lower aluminium levels (Table 2). Conversely, anthills and termite sheathings had lower OM content, $\mathrm{pH}$, exchangeable aluminium and nutrient element concentrations than in the test soil.

\section{SOIL RESPIROMETRY}

Mineralization activity was higher in all the biostructures than in the bulk soil (Table 3 ). This was particularly obvious for earthworm casts and both types of 


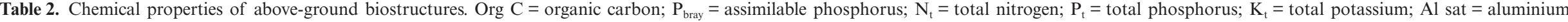

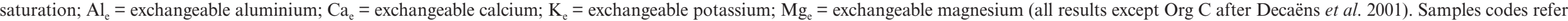
to Table 1; SE in brackets; different letters indicate significant differences at $P<0.05$

\begin{tabular}{|c|c|c|c|c|c|c|c|c|c|c|c|c|}
\hline & & \multirow[b]{2}{*}{$\mathrm{pH}$} & \multirow[b]{2}{*}{ Org C $(\%)$} & \multirow[b]{2}{*}{$\mathrm{P}_{\text {bray }}(\mathrm{ppm})$} & \multicolumn{3}{|l|}{ Total (ppm) } & \multicolumn{4}{|c|}{ Exchangeable (meq100 $\mathrm{g} \mathrm{soil}^{-1}$ ) } & \multirow[b]{2}{*}{ AL sat $(\%)$} \\
\hline & & & & & $\mathrm{N}_{\mathrm{t}}$ & $P_{t}$ & $\mathrm{~K}_{\mathrm{t}}$ & $\mathrm{Al}_{\mathrm{e}}$ & $\mathrm{Ca}_{\mathrm{e}}$ & $\mathrm{Mg}_{\mathrm{e}}$ & $\mathrm{K}_{\mathrm{e}}$ & \\
\hline \multicolumn{13}{|l|}{ Ants } \\
\hline Atta laevigata & A1 & $4 \cdot 0(0 \cdot 0) \mathrm{e}$ & $5 \cdot 6(0 \cdot 3) \mathrm{d}$ & $0 \cdot 5(0 \cdot 0) \mathrm{d}$ & $721(59) \mathrm{c}$ & $192(5) \mathrm{c}$ & $1153(61) \mathrm{c}$ & $1 \cdot 0(0 \cdot 1) \mathrm{c}$ & $0.13(0.06) \mathrm{e}$ & $0 \cdot 11(0 \cdot 05) \mathrm{e}$ & $0 \cdot 21(0 \cdot 02) \mathrm{f}$ & $69 \cdot 3(2 \cdot 7) \mathrm{b}$ \\
\hline Camponotus sp. & A2 & $4 \cdot 5(0 \cdot 2) d$ & $6 \cdot 1(0 \cdot 6) \mathrm{cd}$ & $1 \cdot 4(0 \cdot 2) \mathrm{d}$ & $767(57) \mathrm{c}$ & $185(4) \mathrm{c}$ & $1067(29) \mathrm{c}$ & $1 \cdot 0(0 \cdot 1) \mathrm{b}$ & $0 \cdot 14(0 \cdot 00) \mathrm{e}$ & $0 \cdot 16(0 \cdot 03) \mathrm{e}$ & $0.32(0.02) \mathrm{d}$ & $62 \cdot 8(1 \cdot 2) \mathrm{c}$ \\
\hline Crematogaster sp. & A3 & - & $5 \cdot 7(0 \cdot 1) \mathrm{d}$ & - & - & - & - & - & - & - & - & \\
\hline Pheidole sp. & A4 & $4 \cdot 4(0 \cdot 1) \mathrm{d}$ & $5 \cdot 8(0 \cdot 2) \mathrm{d}$ & $2 \cdot 6(0 \cdot 1) \mathrm{d}$ & $1011(110) \mathrm{c}$ & $206(7) \mathrm{c}$ & $837(27) \mathrm{d}$ & $1 \cdot 7(0 \cdot 0) \mathrm{b}$ & $0.26(0.06) \mathrm{e}$ & $0 \cdot 22(0.03) \mathrm{e}$ & $0 \cdot 14(0 \cdot 04) \mathrm{h}$ & $73 \cdot 6(1 \cdot 1) b$ \\
\hline Acromyrmex landolti & A5 & $4 \cdot 1(0 \cdot 1) \mathrm{d}$ & $5 \cdot 4(0 \cdot 2) \mathrm{d}$ & $1.6(0 \cdot 2) \mathrm{d}$ & $1005(15) \mathrm{c}$ & $202(8) \mathrm{c}$ & $941(32) \mathrm{c}$ & $1 \cdot 8(0 \cdot 0) \mathrm{b}$ & $0 \cdot 17(0.05) \mathrm{e}$ & $0 \cdot 17(0 \cdot 04) \mathrm{e}$ & $0.13(0.00) \mathrm{h}$ & $79 \cdot 5(2 \cdot 2) \mathrm{b}$ \\
\hline Acromyrmex sp. 2 & A6 & - & $6 \cdot 6(0 \cdot 1) \mathrm{c}$ & - & - & - & - & - & - & - & - & \\
\hline Acromyrmex sp. 3 & A7 & - & $5 \cdot 6(0 \cdot 3) \mathrm{d}$ & - & - & - & - & - & - & - & - & \\
\hline Trachymyrmex sp. & A8 & $4 \cdot 4(0 \cdot 1) \mathrm{d}$ & $6 \cdot 3(1 \cdot 3) \mathrm{cd}$ & $1 \cdot 6(0 \cdot 5) \mathrm{d}$ & $886(119) \mathrm{c}$ & $198(5) \mathrm{c}$ & $1052(64) \mathrm{c}$ & $1 \cdot 0(0 \cdot 1) \mathrm{c}$ & $0 \cdot 28(0.05) \mathrm{e}$ & $0 \cdot 29(0 \cdot 05) \mathrm{e}$ & $0 \cdot 26(0 \cdot 01) \mathrm{e}$ & $54 \cdot 6(3 \cdot 4) \mathrm{c}$ \\
\hline \multicolumn{13}{|l|}{ Termites } \\
\hline Microcerotermes sp. & $\mathrm{T} 1$ & $4 \cdot 4(0 \cdot 1) \mathrm{d}$ & $16 \cdot 1(0 \cdot 7) \mathrm{a}$ & $14 \cdot 7(0.7) \mathrm{a}$ & $4578(296) \mathrm{a}$ & 3462 (142) a & $865(27) \mathrm{d}$ & $1 \cdot 4(0 \cdot 0) \mathrm{c}$ & $3 \cdot 81(0.05) \mathrm{a}$ & $3.88(0.08) \mathrm{a}$ & $0.59(0.02) \mathrm{a}$ & $14 \cdot 5(1 \cdot 3) \mathrm{f}$ \\
\hline Velocitermes sp. & $\mathrm{T} 2$ & $4 \cdot 4(0 \cdot 0) \mathrm{d}$ & $9 \cdot 2(0 \cdot 8) \mathrm{b}$ & $7 \cdot 5(0 \cdot 2) \mathrm{b}$ & $2463(60) \mathrm{b}$ & $255(6) c$ & $867(34) d$ & $1.6(0 \cdot 0) \mathrm{c}$ & $1.63(0 \cdot 11) b$ & $1 \cdot 21(0 \cdot 09) \mathrm{b}$ & $0.43(0.01) b$ & $32.8(1.2) \mathrm{e}$ \\
\hline Spinitermes sp. & $\mathrm{T} 3$ & $4 \cdot 7(0 \cdot 0) \mathrm{c}$ & $8 \cdot 5(0 \cdot 2) b$ & $16 \cdot 1(2 \cdot 1) \mathrm{a}$ & 2431 (119) b & $322(5) \mathrm{c}$ & $875(57) d$ & $1 \cdot 8(0 \cdot 1) b$ & $0.64(0.05) \mathrm{d}$ & $0.42(0.05) \mathrm{d}$ & $0.37(0.01) \mathrm{c}$ & $56 \cdot 4(1.5) \mathrm{c}$ \\
\hline Ruptitermes sp. & $\mathrm{T} 4$ & $4 \cdot 0(0 \cdot 0) \mathrm{e}$ & $6.5(0.4) c$ & $1.9(0.0) \mathrm{d}$ & $987(59) \mathrm{c}$ & $184(3) \mathrm{c}$ & $818(12) \mathrm{d}$ & $1 \cdot 4(0 \cdot 2) \mathrm{c}$ & $0 \cdot 20(0.07) \mathrm{e}$ & $0 \cdot 17(0.04) \mathrm{e}$ & $0.08(0.00) \mathrm{i}$ & $74 \cdot 5(3 \cdot 5) b$ \\
\hline Termite sp. & $\mathrm{T} 5$ & - & $14 \cdot 3(1 \cdot 1) \mathrm{a}$ & - & - & - & - & - & - & - & - & \\
\hline \multicolumn{13}{|l|}{ Earthworms } \\
\hline Martiodrilus sp. & E1 & $5 \cdot 2(0 \cdot 1) b$ & $8 \cdot 4(0.6) b$ & $4.2(0.9) \mathrm{c}$ & $2296(61) b$ & $242(6) \mathrm{c}$ & $2156(94) \mathrm{a}$ & $1 \cdot 4(0 \cdot 0) \mathrm{c}$ & $0.94(0.04) \mathrm{c}$ & $0 \cdot 66(0 \cdot 01) \mathrm{c}$ & $0 \cdot 19(0 \cdot 01) \mathrm{g}$ & $3.9(1.3) \mathrm{d}$ \\
\hline Andiodrilus sp. & E2 & $5 \cdot 4(0 \cdot 0) \mathrm{a}$ & $8.6(0.6) b$ & $6.5(0.5) b$ & $2042(37) \mathrm{b}$ & $577(7) b$ & $1925(34) \mathrm{b}$ & $0 \cdot 3(0 \cdot 1) \mathrm{d}$ & $3.84(0.25) \mathrm{a}$ & $0.57(0.01) \mathrm{c}$ & $0 \cdot 16(0.01) \mathrm{h}$ & $6 \cdot 8(2 \cdot 2) \mathrm{g}$ \\
\hline Bulk soil & $\mathrm{BS}$ & $4 \cdot 4(0 \cdot 1) \mathrm{d}$ & $6 \cdot 5(0.6) \mathrm{cd}$ & $1.6(0 \cdot 2) \mathrm{d}$ & $2036(872) b$ & $183(7) \mathrm{c}$ & $1017(30) \mathrm{c}$ & $2 \cdot 9(0 \cdot 1) \mathrm{a}$ & $0.23(0.06) \mathrm{e}$ & $0 \cdot 14(0 \cdot 01) \mathrm{e}$ & $0.14(0.03) \mathrm{h}$ & $85 \cdot 2(1 \cdot 2) \mathrm{a}$ \\
\hline
\end{tabular}


Functional

signature in soil macro-invertebrate biostructures

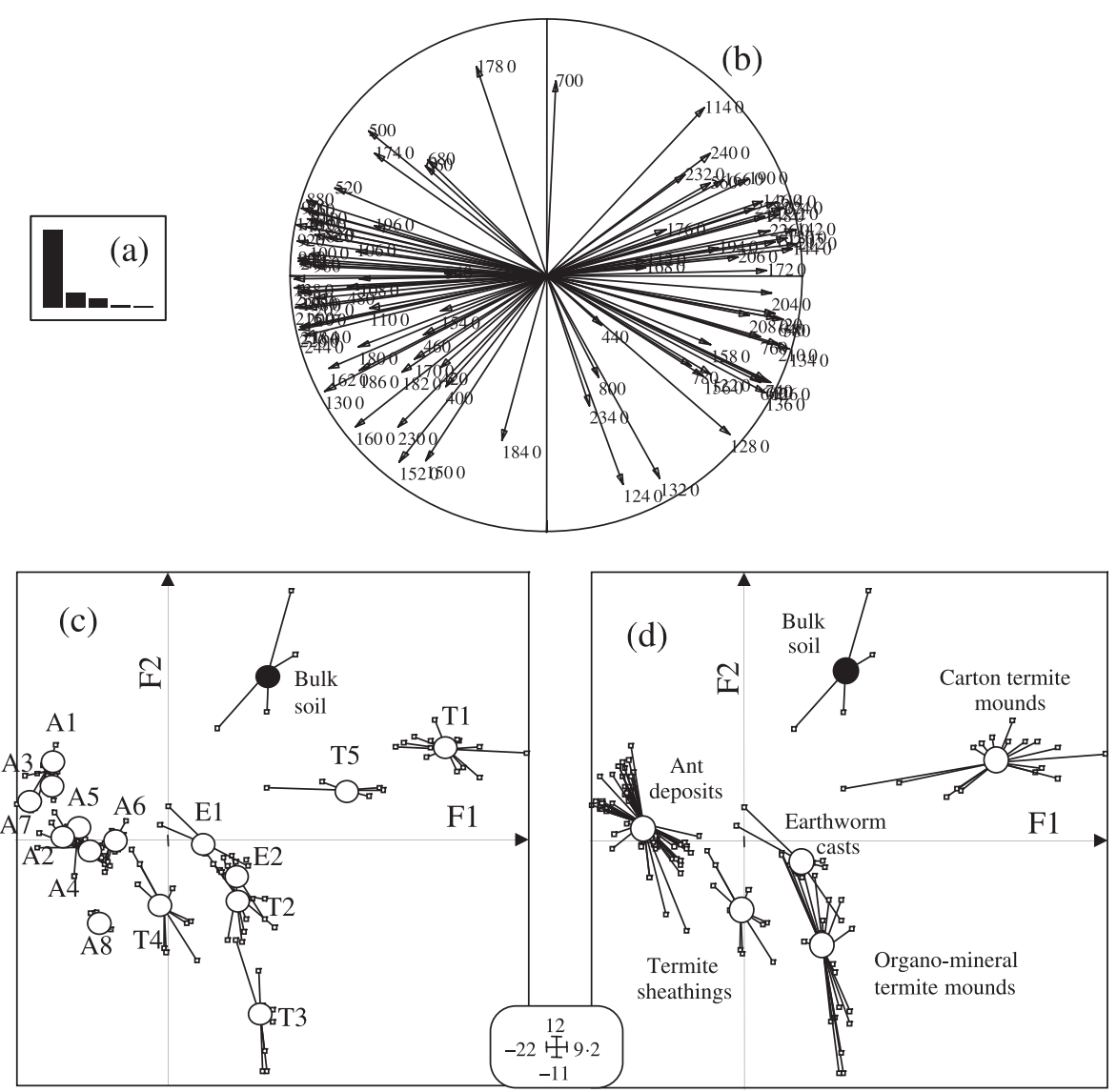

Fig. 1. PCA of the NIRS spectra of the 15 identified above-ground biostructures (codes refer to Table 1): (a) eigenvalue diagram; (b) correlation circle on F1-F2 plan; (c) ordination of biostructures on F1-F2 plan according to engineer taxa or (d) according to broad biostructure types; bulk soil was projected as additional columns. Species codes refer to Table 1.

Table 3. Accumulated $\mathrm{CO}_{2}$ release $\left(\mathrm{mg} \mathrm{C}-\mathrm{CO}_{2} \mathrm{~g}\right.$ carbon ${ }^{-1}$, mean $\pm \mathrm{SD}$ ) in the above-ground biostructures after 1,2 and 3 weeks of incubation in standard laboratory conditions. Different letters indicate significant differences at $P<0.05$

\begin{tabular}{|c|c|c|c|c|}
\hline & $n$ & 1 week & 2 weeks & 3 weeks \\
\hline Atta laevigata & 10 & $3 \cdot 36(0 \cdot 90) \mathrm{a}$ & $3.74(1.02) \mathrm{c}$ & $4 \cdot 11(1 \cdot 16) \mathrm{f}$ \\
\hline Camponotus sp. & 10 & $8.46(1.08) \mathrm{a}$ & $11.08(1.22) b c$ & $14 \cdot 00(1 \cdot 67) \mathrm{cd}$ \\
\hline Crematogaster sp. & 10 & $6.41(0.42) \mathrm{a}$ & $7 \cdot 56(0 \cdot 50) \mathrm{bc}$ & $8.76(0.76) \mathrm{e}$ \\
\hline Pheidole sp. & 10 & $7 \cdot 87(1 \cdot 87) \mathrm{a}$ & $9 \cdot 37(2 \cdot 47) \mathrm{bc}$ & $11 \cdot 53(3 \cdot 70) \mathrm{de}$ \\
\hline Acromyrmex landolti & 3 & $6.47(1.69) \mathrm{a}$ & $8.07(1.96) \mathrm{bc}$ & $9 \cdot 80(2 \cdot 20) \mathrm{de}$ \\
\hline Acromyrmex sp. 2 & 10 & $9 \cdot 78(4.60) \mathrm{a}$ & $12 \cdot 51(4 \cdot 58) b c$ & $15 \cdot 70(5 \cdot 18) \mathrm{cd}$ \\
\hline Acromyrmex sp. 3 & 10 & $4.89(1.26) \mathrm{a}$ & $6.06(1.69) \mathrm{bc}$ & $7 \cdot 55(2 \cdot 36) \mathrm{e}$ \\
\hline Trachymyrmex sp. & 4 & $13 \cdot 30(4 \cdot 16) \mathrm{a}$ & $15 \cdot 88(4 \cdot 54) \mathrm{abc}$ & $18 \cdot 61(5 \cdot 13) \mathrm{bcd}$ \\
\hline Microcerotermes sp. & 10 & $27 \cdot 35(18.89) \mathrm{a}$ & $39 \cdot 22(25 \cdot 77) \mathrm{a}$ & $52 \cdot 16(31 \cdot 55) \mathrm{a}$ \\
\hline Velocitermes sp. & 10 & $18 \cdot 32(6 \cdot 13) \mathrm{a}$ & $24 \cdot 91(7 \cdot 14) \mathrm{ab}$ & $31 \cdot 73(8 \cdot 80) \mathrm{ab}$ \\
\hline Spinitermes sp. & 10 & $17 \cdot 41(4 \cdot 43) \mathrm{a}$ & $24 \cdot 40(5 \cdot 59) a b$ & $31 \cdot 37(6 \cdot 78) a b$ \\
\hline Ruptitermes sp. & 10 & $10 \cdot 77(4 \cdot 35) \mathrm{a}$ & $14 \cdot 20(5 \cdot 89) \mathrm{bc}$ & $18 \cdot 88(8.00) \mathrm{cd}$ \\
\hline Termite sp. & 5 & $13 \cdot 48(6 \cdot 14) \mathrm{a}$ & $19 \cdot 80(9 \cdot 00) \mathrm{abc}$ & $26 \cdot 06(10 \cdot 85) b c$ \\
\hline Martiodrilus sp. & 5 & $12.43(4.43) \mathrm{a}$ & $17 \cdot 01(5 \cdot 78) a b c$ & $22 \cdot 93(7 \cdot 68) b c$ \\
\hline Andiodrilus sp. & 5 & $12 \cdot 30(1 \cdot 78) \mathrm{a}$ & $16 \cdot 75(2 \cdot 58) \mathrm{abc}$ & $22 \cdot 42(3 \cdot 75) b c$ \\
\hline Bulk soil & 5 & $4 \cdot 53(1 \cdot 16) \mathrm{a}$ & $5.55(1.46) b c$ & $7 \cdot 04(2 \cdot 00)$ ef \\
\hline
\end{tabular}

termite mounds, in which production of $\mathrm{CO}_{2}$ continuously increased with time, with highest values obtained after 21 days of incubation. By comparison, ant deposits and termite sheathings showed significantly lower mineralization rates $(P<0 \cdot 05)$, close to those measured

in the bulk soil.

\section{MULTIPLE CO-INERTIA ANALYSIS}

The first axis of the ACOM absorbed $71 \%$ of the total covariance between the three matrices, and was the only one retained for interpretation owing to the rapid decline in eigenvalues (Fig. 2a). There were only

\section{Ecological Society, Functional Ecology, 19, 785-793 \\ (C) 2005 British}



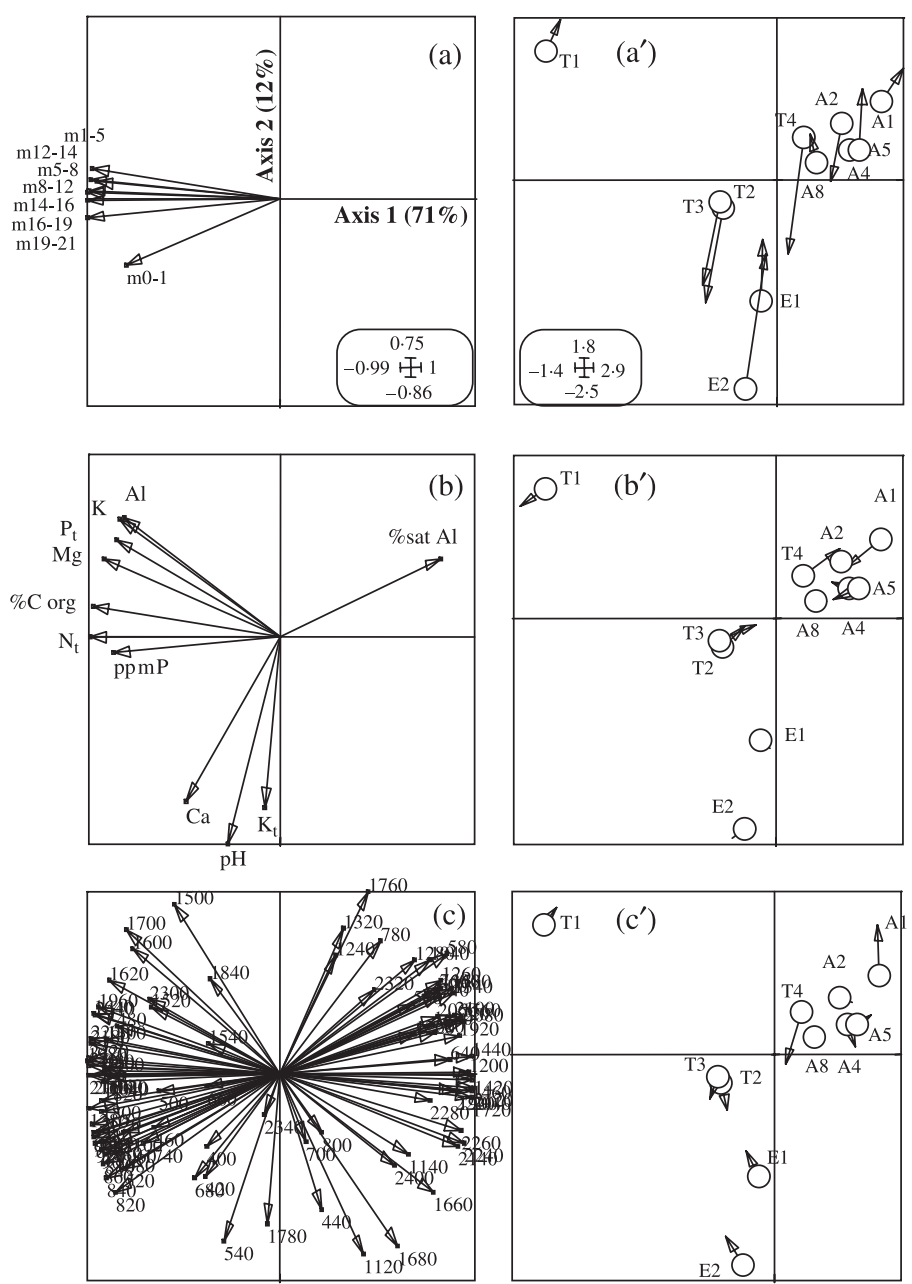

Fig. 2. ACOM performed on chemical properties, potential mineralization and NIRS spectra of 11 different above-ground biostructures: each initial set of variable is projected on the compromise plan: (a) potential mineralization at different time of incubation; (b) chemical properties and (c) NIRS wavelengths. For each data set, biostructure ordination is represented (arrow heads) together with their ordination on the compromise plan (circles) ( $a^{\prime}$ to $\left.c^{\prime}\right)$. Codes refer to Tables 1 and 2.

slight differences in the ordination of the 11 types of biostructures according to NIRS spectra, chemical and respirometric variables (Fig. 2). Ant deposits and termite sheathings with positive scores on the first axis, were characterized by high levels of aluminium saturation, low values for the other entire chemical parameters and low mineralization rates (Fig. 2a-c). The opposite pattern was found for the carton mounds of Microcerotermes sp., which had negative scores on axis 1 , with high values for all the chemical parameters except for aluminium saturation and high mineralization rates. Earthworm casts and organo-mineral termite mounds presented intermediate scores.

\section{Discussion}

(C) 2005 British Ecological Society, Functional Ecology, 19, 785-793
ORGANIC SIGNATURE OF BIOGENIC STRUCTURES

NIRS spectra may be considered as fingerprints of the OM composition (Gillon, Joffre \& Ibrahima 1999;
Joffre et al. 2001). In this study, we show for the first time that structures produced by different ecosystem engineers can be clearly separated according to this criterion in spite of the noise added to the signal by the mineral matrix. The use of multivariate analysis clearly underlined that the modifications of soil OM caused by ecosystem engineering result in species-specific organic fingerprints in their respective above-ground biostructures. These fingerprints and other properties of biostructures provide a method for novel functional classification of soil ecosystem engineers that can be derived from the ordination of a large set of similar data collected under a broad range of ecological conditions. Given the importance of aggregation in all soil processes, this finding may be considered a breakthrough in our quest to relate biodiversity in soil organisms, especially ecosystem engineers, and soil function (Hooper et al. 2000; Lavelle et al. 2004b).

Differences observed between biostructures result from the combination of three different factors. First, structures produced after gut transit (earthworm casts and mounds of humivorous termites) present higher OM contents than structures made by displacement of soil particles (ant deposits, termite sheathings). Second, the nature of the substrate(s) ingested by soil invertebrates and the addition of intestinal mucus or saliva during biostructure production are further reflected in NIRS signatures. Earthworm casts may contain at least some traces of intestinal mucus secreted during the digestion process and largely reabsorbed at the end of the gut (Martin et al. 1987). Termites use their saliva as an organic glue to assemble particles during the construction of the mounds and sheathings (see review by Brauman 2000). Contrary to earthworm casts and termite mounds, ant artefacts seem to be mainly constituted by separated soil particles (Elmes 1991). Finally, specific microbial activities in the gut of some engineer species and in their fresh biostructures probably affect the OM molecular composition via the production of specific mucigel and cellular compounds (Martin \& Marinissen 1993; Harry et al. 2001; Lavelle et al. 2004c).

These three factors merely explain the variability in OM biochemical composition emphasized by the PCA. The first principal component was related to a gradient of OM concentration in the biostructures, which separated almost completely mineral ant artefacts from organic termite mounds, with intermediate positions for organo-mineral earthworm casts and termite mounds. This ordination clearly separated non-geophagous from geophagous species, with an increased microbial activity resulting from mutualistic digestion during earthworm and termite gut transit (Lavelle \& Spain 2001).

Interestingly, control soil was closely associated with earthworm casts and termite mounds in factorial representations, suggesting a great participation of these organisms in soil aggregate formation. This hypothesis is largely supported by quantitative estimations, which have demonstrated that both earthworm and termite 
Functional signature in soil macro-invertebrate biostructures
(C) 2005 British

Ecological Society, Functional Ecology, 19, 785-793 organo-mineral constructions are the two dominant above-ground biostructures in the Carimagua's savannas (Decaëns et al. 2002).

\section{CARBON POTENTIAL MINERALIZATION}

Results from the mineralization tests separated termite mounds and earthworm casts with high mineralization rates, from ant deposits and termite sheathings with opposite characteristics. It must also be stressed that significant differences may occur within each groups, exemplified by the high values observed in Microcerotermes sp. carton mounds as compared with other termite mound material.

In the field, structures with high potential mineralization rates also had high structural stability. Diverse experiments have shown that earthworm casts may keep their physical integrity for periods of months to several years depending on their clay contents and their location in the soil profile (Blanchart et al. 1997; Decaëns 2000). On the other hand, small ant deposits, fresh earthworm casts or termite sheathings may be destroyed by a single important rain event (Blanchart, Bruand \& Lavelle 1993; T. Decaëns \& J. J. Jiménez, personal observation). As a consequence, OM protected inside biostructures only becomes available to microorganisms when biostructures are dispersed or crushed (as done artificially in our laboratory test) (Martin 1991). In our results, differences in potential OM mineralization therefore reflect differences in OM chemical protection against microbial activity rather than physical protection, i.e. differences in the concentration of easily available $\mathrm{C}$ for microbial communities.

As previously discussed, earthworm casts and termite mounds mostly differ from ant artefacts and termite sheathings by the origin of their OM, and the gut transit experienced before structure building (Brauman et al. 2001; Kapler \& Brune 2002). Thus, resource quality for microorganisms in biostructures mostly results from the combined effect of engineer foraging specificity (Jiménez et al. 1998; Jiménez, Rossi \& Lavelle 2001; Mariani et al. 2001) and outputs of the digestive mutualistic interactions (Lavelle \& Gilot 1994; Lavelle et al. 1995), both mechanisms leading to differences in the OM humification rates.

\section{CLASSIFICATION OF THE BIOSTRUCTURES}

In a pioneer study dedicated to the same set of species, Decaëns et al. (2001) proposed a tentative classification of biostructures based on physico-chemical characteristics. Our findings support the results of this preliminary study, and provide additional data to infer the functional traits of soil engineers from the properties of their biostructures. Three broad functional groups of engineers may thus be proposed:

1. Accumulators of protected OM. Carton termite mounds are clearly the most different from the average soil, and also differ from other types of structures in most parameters. These holorganic structures present a specific OM biochemical composition and high potential mineralization rates. Although their life span is not known with any certainty, they may constitute a pool of protected OM, which may be mineralized only if/when the mound is destroyed.

2. Soil compactors. Organo-mineral termite mounds and earthworm casts are compact structures with high structural stability and overall properties relatively similar to the bulk soil. Their low mineralization rates reflect a lower concentration of $\mathrm{OM}$ and a more efficient chemical protection than carton termite mounds. Therefore, whatever their life span, their OM probably remains protected for a long period of time after their disruption.

3. Soil decompactors. Ant mounds and termite sheathings are characterized by a loose structure and low organic contents and mineralization rates. The impact of these structures on soil OM dynamics is expected to be limited whereas they probably influence soil physical properties by bringing to the surface deep material with specific granulometric characteristics. They participate in the disruption of stable organo-mineral aggregates and have been for this reason defined as decompacting species (Blanchart et al. 1999).

Ecological functions of all soil macro-invertebrates are not likely to fit into three categories only. We propose to classify them in a continuous mode, according to a set of relevant biological traits considered to be predictors of their function in soil. Diaz et al. (1999) proposed a distinction between 'soft' biological traits, that are easily measurable, which in turn enable prediction of 'hard' traits, i.e. characters that have direct functional implications although they are very difficult or impossible to measure. Biostructures can be definitively considered as hard biological traits since their nature, accumulation and distribution may clearly affect critical soil processes (Lavelle 1996).

\section{Acknowledgements}

The authors are grateful to F. Reversat (IRD, Bondy) and M. Harry and S. Abbad-Andaloussi (Univ. Paris 12) for their technical support concerning respirometry measurements. Sincere thanks to P. Margerie and M. Aubert (University of Rouen) for useful comments on an early version of the manuscript.

\section{References}

Anderson, J.M. (1993) Soil organisms as engineers: microsite modulation of macroscale process. Linking Species and Ecosystems (eds C.G. Jones \& J.H. Lawton), pp. 94-106. Chapman \& Hall, New York.

Anderson, J.M. \& Ingram, J.S. (1993) Tropical Soil Biology and Fertility: a Handbook of Methods, 2nd edn. CAB International, Oxford. 
M. Hedde et al.

Blanchart, E., Albrecht, A., Alegre, J., Duboisset, A., Gilot, C., Pashanasi, B., Lavelle, P. \& Brussaard, L. (1999) Effects of earthworms on soil structure and physical properties. Earthworm Management in Tropical Agroecosystems (eds P. Lavelle, L. Brussaard \& P. Hendrix), pp. 149-172. CAB International, Wallingford.

Blanchart, E., Bruand, A. \& Lavelle, P. (1993) The physical structure of casts of Millsonia anomala (Oligochaeta: Megascolecidae) in shrub savanna soils (Côte d'Ivoire). Geoderma 56, 119-132.

Blanchart, E., Lavelle, P., Braudeau, E., Le Buissonnais, Y. \& Valentin, C. (1997) Regulation of soil structure by geophageous earthworms activities in humid savannas of Côte d'Ivoire. Soil Biology and Biochemistry 29 (3/4), 431439.

Brauman, A. (2000) Effect of gut transit and mound deposit on soil organic matter transformations in the soil feeding termite: a review. European Journal of Soil Biology 36, 117-125.

Brauman, A., Doré, J., Eggleton, P., Bignell, D., Breznak, J.A. \& Kane, M.D. (2001) Molecular phylogenetic profiling of prokaryotic communities in guts of termites with different feeding habits. FEMS Microbiology Ecology 35, 27-36.

Chauvel, A., Grimaldi, M., Barros, E., Blanchart, E., Desjardins, T., Sarrazin, M. \& Lavelle, P. (1999) Pasture degradation by an Amazonian earthworm. Nature 389, 32-33.

Chessel, D. \& Hanafi, M. (1996) Analyses de la co-inertie de K nuages de points. Revue de Statistique Appliquée XLIV 2 , $35-60$.

Davidson, D.A., Bruneau, P.M.D., Grieve, I.E. \& Young, I.M. (2002) Impacts of fauna on an upland grassland soil as determined by micromorphological analysis. Applied Soil Ecology 20, 133-143.

Decaëns, T. (2000) Degradation dynamics of surface earthworms casts in grassland of the eastern plains of Colombia. Biology and Fertility of Soils 32, 149-156. Amézquita, E. (2002) Surface activity of ecostem engineers and soil structure in contrasted land use systems of Colombia. European Journal of Soil Biology 38, 267-271.

Decaëns, T., Galvis, J.H. \& Amezquita, E. (2001) Propriétés des structures produites par les ingénieurs écologiques à la surface du sol d'une savane colombienne. Compte-Rendus de l'Académie Des Sciences 324, 465-477.

Decaëns, T., Mariani, L. \& Lavelle, P. (1999) Soil surface macrofaunal communities associated with earthworm casts in grasslands of the Eastern Plains of Colombia. Applied Soil Ecology 13, 87-100.

Demattê, J.A.M., Campos, R.C., Alves, M.C., Fiorio, P.R. \& Nanni, M.R. (2004) Visible-NIR reflectance: a new approach on soil evaluation. Geoderma 121, 95-112.

Diaz, S., Cabido, M., Zak, M., Carretero, E.M. \& Aranibar, J. (1999) Plant functional traits, ecosystem structure and land-use history along a climatic gradient in central-western Argentina. Journal of Vegetation Science 10, 651-660.

Diouf, M.N. (2003) Les communautés fongiques des structures de récolte de plusieurs espèces de termites Macrotermitinae: origine et évolution. Thèse, l'Université Paris XII, Paris.

Elmes, G.W. (1991) Ant colonies and environmental disturbance. Symposium of the Zoological Society of London 63, 15-32.

Foley, W.J., McIlwee, A., Lawler, I., Aragones, L., Woolnough, A.P. \& Berding, N. (1998) Ecological applications of near infrared reflectance spectroscopy a tool for rapid, costeffective prediction of the composition of plant and animal tissues and aspects of animal performance. Oecologia 116, 293-305.

Gillon, D., Houssard, C. \& Joffre, R. (1999) Using NIRS to predict carbon, nitrogen and phosphorus content in heterogeneous plant material. Oecologia 118, 173-182.

Ecological Society, Functional Ecology, 19, 785-793

Gillon, D., Joffre, R. \& Ibrahima, A. (1999) Can litter decomposability be predicted by near-infrared reflectance spec-
Decaëns, T., Asakawa, N., Galvis, J.H., Thomas, R.J. \&

Harry, M., Jusseaume, N., Gambier, B. \& Garnier-Sillam, E. (2001) Use of RAPD makers for the study of microbial community similarity from termite mounds and tropical soils. Soil Biology and Biochemistry 33, 417-427.

Hooper, D.U., Bignell, D.E., Brown, V.K., Brussaard, L., Dangerfield, J.M., Wall, D.H., Wardle, D.A., Coleman, D.C., Giller, K.E., Lavelle, P., van der Putten, W.H., de Ruiter, P.C., Rusek, J., Silver, W., Tiedje, J.M. \& Wolters, V. (2000) Interactions between above- and belowground biodiversity in terrestrial ecosystems: patterns, mechanisms, and feedbacks. Bioscience 50, 1049-1061.

Jiménez, J.J., Moreno, A.G., Lavelle, P. \& Decaëns, T. (1998) Population dynamics and adaptatives strategies of Martiodrilus carimaguensis (Oligochaeta, Glossoscolecidae), a native species from the well-drained savannas of Colombia. Applied Soil Ecology 9, 153-160.

Jiménez, J.J., Rossi, J.-P. \& Lavelle, P. (2001) Spatial distribution of earthworms in acid-soil savannas of the eastern plains of Colombia. Applied Soil Ecology 17, 267-278.

Joffre, R., Agren, G.I., Gillon, D. \& Bosatta, E. (2001) Organic matter quality in ecological studies: theories meets experiment. Oikos 93, 451-458.

Jones, C.G., Lawton, J.H. \& Shachak, M. (1994) Organisms as ecosystem engineers. Oikos 69, 373-386.

Kapler, A. \& Brune, A. (2002) Dynamics of redox potential and changes in redox state of iron and humic acids during gut passage in soil-feeding termites (Cubitermes spp). Soil Biology and Biochemistry 34, 221-227.

Lavelle, P. (1996) Diversity of soil fauna and ecosystem function. Biology International 33, 3-16.

Lavelle, P., Bignell, D., Austen, M., Giller, P., Behan-Pelletier, V., Garey, V., Hawkins, P., Brown, G., St John, M., Hunt, W. \& Paul, E. (2004a) Vulnerability of ecosystem services at different scales: role of biodiversity and implications for management. Sustaining Biodiversity and Functioning in Soils and Sediments (ed. D.H. Wall), pp. 213-224. Island Press, New York.

Lavelle, P., Charpentier, F., Gilot, C., Rossi, J.P., Pashanasi, B., Derouard, L., André, J., Ponge, J.F. \& Bernier, N. (2004b) Effects of earthworms on soil organic matter and nutrient dynamics at a landscape scale over decades. Earthworm Ecology, 2nd edn. (ed. C.E. Edwards), pp. 145-160. CRC Press Boca, Raton.

Lavelle, P. \& Gilot, C. (1994) Priming effects of macroorganisms on microflora: a key process of soil function? Beyond the Biomass (eds K. Ritz, J. Dighton \& K.E. Giller), pp. 176-181. Wiley-Sayce, Chichester.

Lavelle, P., Lattaud, C., Trigo, D. \& Barois, I. (1995) Mutualism and biodiversity in soils. The Significance and Regulation of Soil Biodiversity (eds H.P. Collins, G.P. Robertson \& M.J. Klug), pp. 23-33. Kluwer Academic Publishers, Dordrecht.

Lavelle, P., Rouland, C., Binet, F., Diouf, M. \& Kersanté, A. (2004c) Regulation of Microbial Activities by Roots and Soil Invertebrates. Springer Verlag, Berlin.

Lavelle, P. \& Spain, A.V. (2001) Soil Ecology. Kluwer Scientific Publications, Amsterdam.

Lilliefors, H.W. (1967) The Kolmogorov-Smirnov-test for normality with mean and variance unknown. Journal of American Statistic Association 62, 399-402.

Loranger, G., Ponge, J.F., Blanchart, E. \& Lavelle, P. (1998) Impact of earthworms on the diversity of microarthropods in a vertisol (Martinique). Biology and Fertility of Soils 27, 21-26.

Mariani, L., Bernier, N., Jiménez, J.J. \& Decaëns, T. (2001) Régime alimentaire d'un ver de terre anécique des savanes colombiennes: une remise en question des types écologiques. Compte Rendu de l'Académie Des Sciences 324, 733742. troscopy. Ecology 80, 175-186.
Martin, A. (1991) Short- and long-term effects of the endogeic earhworm Millsonia anomala (Omodeo) (Megascolecidae, 


\section{3}

Functional signature in soil macro-invertebrate biostructures
Oligochaeta) of tropical savannas, on soil organic matter. Biology and Fertility of Soils 11, 234-238.

Martin, A., Cortez, J., Barois, I. \& Lavelle, P. (1987) Les mucus intestinaux de ver de terre moteur de leurs interactions avec la microflore. Revue d'Ecologie et de Biologie Des Sols 24 (4), 549-558.

Martin, A. \& Marinissen, J.C.Y. (1993) Biological and physico-chemical processes in excrements of soil animals. Geoderma 56, 331-347.

Moore, J.C., McCann, K., Setälä, H. \& de Ruiter, P.C. (2003) Top-down is bottom-up: does predation in the rhizosphere regulate aboveground dynamics? Ecology 84, 846-857.

Mora, P., Seugé, C., Chotte, J.L. \& Rouland, C. (2003) Physico-chemical typology of the biogenic structures of termites and earthworms: a comparative analysis. Biology and Fertility of Soils 37, 245-249.

Reeves, J.B., McCarty, G.W. \& Meisenger, J.J. (1999) Near infrared reflectance spectroscopy for the analysis of agricultural soils. Near Infrared Spectroscopy 7, 179193. de Ruiter, P.C., Neutel, A.-M. \& Moore, J.C. (1998) Biodiversity in soil ecosystems: the role of energy flow and community stability. Applied Soil Ecology 10, 217-228.

Schrader, S. \& Zhang, H. (1997) Earthworm casting: stabilization or destabilization of structure? Soil Biology and Biochemistry 29 (3/4), 469-475.

Shenk, J.S. \& Westerhaus, M.O. (1991) ISI NIRS-2. Software for near-infrared instrument. InfraSoft International, Silverspring, USA.

Shepherd, K.D. \& Walsh, M.G. (2002) Development of reflectance spectral libraries for characterization of soil properties. Soil Science Society of America Journal 66, 988-998.

Siesler, H.W. (2002) Introduction. Near-Infrared Spectroscopy. Principles, Instruments, Applications (eds H.W. Siesler, Y. Ozaki, S. Kawata \& H.M. Heise), pp. 1-10. Wiley, Weinheim.

Thioulouse, J., Chessel, D., Dolédec, S. \& Olivier, J.-M. (1997) ADE-4: a multivariate analysis and graphical display software. Statistic Computer 7, 5-83.

Received 19 April 2005; accepted 26 April 2005
(C) 2005 British Ecological Society, Functional Ecology, 19, 785-793 